Удк 378.14.024

DOI 10.31494/2412-9208-2021-1-2-313-320

MODERN APPROACHES TO THE CREATION OF A TEXTBOOK ON MEDICAL AND BIOLOGICAL PHYSICS FOR MEDICAL UNIVERSITY STUDENTS

\title{
СУЧАСНІ ПІДХОДИ ДО СТВОРЕННЯ ПІДРУЧНИКА 3 МЕДИЧНОЇ ТА БІОЛОГІЧНОЇ ФІЗИКИ ДЛЯ СТУДЕНТІВ МЕДИЧНОГО УНІВЕРСИТЕТУ
}

Tatyana TOCHILINA, Candidate of Pedagogical Sciences, Associate Professor

toch2008mail.ru@gmail.com http://orcid.org/0000-0002-4886-9720

Zaporizhzhya State Medical University

Street Mayakovsky, 26.

Zaporizhzhya, 69036

Artem TOCHILIN,

1st year student of the Faculty of

Physics

artem3126270104@gmail.com

Taras Shevchenko National

University of Kyiv

Academician Glushkov Avenue,

4. Kyiv, 03680

Irina FILIPPENKO,

Candidate of Pedagogical Sciences,

Associate Professor

ir09fil@gmail.com університет ім. Тараса Шевченка

$\triangle$ проспект Академика

Глушкова, 4. м.Київ, 03680

Ірина ФІЛІППЕНКО,

кандидат педагогічних наук, доцент

\section{http://orcid.org/0000-0002-6668-2599}

Zaporizhzhya State Medical University

26, Mayakovsky st.

Zaporizhzhya, 69036

Запорізький державний медичний університет

вул. Маяковського, 26,

м. Запоріжжя, 69036

Original manuscript received: June 18, 2021

Revised manuscript accepted: September 15, 2021

\section{ABSTRACT}

The proposed article analyzes the role of physics in the development of modern medicine. The principles of effective teaching of medical and biological physics are considered. The conditions which provide formation of positive motivation of educational activity in the course of training to medical physics are opened. Defining the main pedagogical functions of the textbook in the educational process. The analysis of some problems of the existing textbooks on medical physics for higher 
medical educational institutions is made and the possible ways of their decision are offered. The structural-logical analysis of the educational text of the content module "Bioacoustics. Biophysics of the senses. Fundamentals of audiometry», The statement of the content of the theory in the textbook "Medical and biological physics» Chaly O.V. is analyzed. The description of the basic structural elements of the textbook on medical physics developed by us is given. Modern approaches to the organization of the educational process using an electronic textbook on medical physics are considered. It is concluded that the reduction of the textbook due to the reduction of mathematical calculations and calculations should not lead to the exclusion from the educational process of work on this material. We consider it expedient to transfer calculations and conclusions of laws and formulas to the collection for practical classes. In our opinion, the combination of electronic textbooks with programs that control knowledge, supplemented by communication between teacher and student in real time have great potential for effective learning, including distance learning.

Key words: medical physics, biomedical research, medical technologies, learning efficiency, electronic textbook.

Вступ. Компетенції випускника будь-якого закладу вищої освіти мають дозволити йому успішно працювати в обраній професійній сфері, набувати соціально-особистісних і загальнокультурних якостей, що сприяють його соціальній мобільності і стійкості на ринку праці. У вирішенні цього завдання важлива роль належить фізиці, яка має низку особливостей, що дозволяють розвивати в студентів логіку, раціональність і системність мислення. На сучасному етапі наукового розвитку фізика активно впроваджується в медицину: лазерна хірургія, ультразвукові дослідження м'яких тканин, магнітно-резонансна томографія, рентгенодіагностика, позитронно-емісійна томографія, операції за допомогою гама-скальпеля і ін. Безумовно, фрізика як найважливіша галузь природознавства потрібна майбутньому лікарю для формування базових уявлень про функціонування основних систем організму людини і для осмисленого застосування цих уявлень у майбутній лікарській діяльності. Лікар зобов'язаний розуміти фрізичні закони і принципи, що лежать в основі роботи медичного обладнання, та правильно інтерпретувати результати діагностичного дослідження.

Методи та методики дослідження. Курс медичної і біологічної фрізики, який вивчається в медичних 3 ВО на першому курсі, не $\epsilon$ профілюючим предметом для студентів, але важливим з точки зору підготовки висококваліфікованого лікаря. Підвищення ефективності навчання медичної фрізики $є$ актуальною проблемою, а одним із його принципів - принцип стимулювання і мотивації, орієнтація на потреби студента і його інтереси.

Із загальної теорії діяльності відомо, що неможливо досягти належного ефекту за відведений час, якщо не забезпечена відповідна мотивація. Головним чинником при відборі змісту, розробці навчальнометодичних матеріалів, технологій навчання повинна стати орієнтація на потреби і запити студента. Умови, які забезпечують фрормування позитивної мотивації навчальної діяльності в процесі навчання медичній 
фізиці, на наш погляд, такі: а) компетентність викладача при формуванні мотивації; б) безперервність діяльності щодо формування мотивації; в) спеціальний підбір методичних прийомів, форм навчання, що забезпечують розвиток мотивації; г) професійна спрямованість навчально-методичних матеріалів. Професійна спрямованість не тільки $€$ мотивацією для студентів в вивченні медичної фрізики, але й необхідна у зв'язку з обмеженим обсягом курсу медичної фрізики в медичних ЗВО.

Актуальним $є$ розробка принципово нового підручника з медичної фрізики, тому що йому відводиться особливе функціональне навантаження. Підручник повинен бути моделлю процесу навчання, тобто визначати його контури, загальну логіку, реалізацію всіх його провідних елементів. У ньому мають бути представлені конкретні дидактичні матеріали, які відповідають навчальній програмі, професійна спрямованість, послідовність їх реалізації в освітньому процесі.

На необхідність глибокого функціонального аналізу підручників, навчальних посібників та іншої літератури неодноразово вказували дослідники А. Архипова, П. Атаманчук, С. Батишев, В. Беспалько, Б. Гершунський та ін. Так, Г. Маендорф на основі численних досліджень дійшов висновку, що, займаючись питаннями розробки будь-якого підручника, треба починати з визначення його функцій. Цікаву, глибоко продуману схему інтеграційної і координаційної функцій підручника запропонував С. Шаповаленко (Шаповаленко, 2004). Тому, розглядаючи підручник як основне ядро системи засобів навчання і спираючись на системно-структурний аналіз підручників, виконаний у дослідженнях С. Шаповаленка, ми виділили основні педагогічні функції підручника 3 медичної фрізики: інформаційна; систематизаційна; трансформаційна; закріплення і самоконтролю; самоосвіти; інтеграційна; координаційна (Точиліна, 2012).

Результати та дискусії. Підручники з медичної фрізики, які використовуються десятиліттями у вищих медичних закладах освіти, застаріли і їх складно застосовувати в сучасних умовах навчання. Необхідно провести відбір змісту курсу медичної фізики для студентівмедиків різних спеціальностей; переглянути форму побудови підручників, яка на всіх етапах розвитку вищої освіти не змінювалася, оновлення змісту має супроводжуватися розвитком форми підручника, зміною його структури. Ми проаналізували деякі проблеми підручників (Чалий, 2017) з медичної фізики для медичних ЗВО і можливі шляхи їх удосконалення.

Одна з головних проблем - підручник і студент. Однаковість типового підручника, орієнтованого на абстрактну модель студента, обмежує можливості виявлення його індивідуальних навчальних інтересів. Тому необхідно вирішити проблему градації навчального матеріалу, що дозволило б зробити вибір студентам з різним рівнем підготовки. Не менш важливою проблемою $є$ перевантаження студентів навчальним матеріалом. Необхідно використати таку форму побудови навчального матеріалу в підручнику, яка дозволила б зробити 
обсяг параграфа мінімальним. Однак мінімізація обсягу підручника не повинна привести до догматичної подачі матеріалу.

Ми зробили структурно-логічний аналіз навчального тексту змістового модуля «Біоакустика. Біофізика чуття. Основи аудіометрії», проаналізувавши виклад змісту теорії в підручнику «Медична та біологічна фізика» Чалого О. В. Ми виділили кількість самостійних завершених логічних порцій навчального тексту і розбили їх на дві групи: основні і другорядні (Точиліна, 2012).

Логіко-змістовий аналіз навчального тексту показав наявність двох кількісних показників: загальну кількість логічних порцій матеріалу і основних з них, які виражають головні ідеї теорії. Для змістового модуля «Елементи квантової фрізики» характерне таке співвідношення $\mathrm{A}=2 \mathrm{~A}_{0}$

$\mathbb{Q}$ Кількість основних логічних порцій (A0)

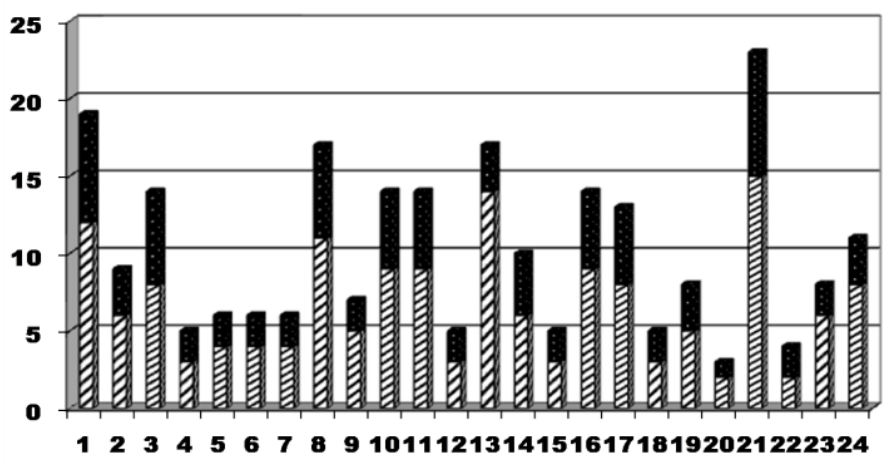

Puc. 1. Порівняльна гістограма логіко-змістового навантаження змістового модуля “Біоакустика. Біофізика чуття. Основи аудіометріі”

Важливий висновок аналізу також полягає в тому, що, якщо в текст параграфа підручника включити лише основний матеріал, то його обсяг скорочується приблизно в два рази (це стосується аналізованого змістового модуля). Ми вважаємо, що цей висновок доцільно враховувати при розробці підручника нового покоління, у якому основні логічні порції можна включити в теоретичну частину, а другорядний і ілюстративний матеріал - у дидактичну. Скорочення обсягу другорядного матеріалу - один зі шляхів вирішення проблеми перевантаження студентів навчальним матеріалом. При цьому виключається дублювання матеріалу, а студенти привчаються користуватися додатковою навчальною літературою.

Останнім часом викладачі й психологи констатують зниження інтересу в студентів до навчання. Певною мірою виною цьому $\epsilon$ недосконалі підручники. Треба особливу увагу звернути на мову й 
стиль спілкування зі студентом. Виклад матеріалу нерідко непослідовний, фррагментарний, 3 використанням довгих речень, незрозумілих математичних викладок, складних конструкцій. Отже, формування позитивних мотивів навчання знаходить реальне відображення у формі й змісті підручника нового типу. При цьому різноманітність форм необхідна для вирішення іншої проблеми підручника - підручник і викладач.

Прийнята форма підручників не допомагає викладачу розробити методику заняття, оскільки матеріал однорідний, ускладнена диференціація навчання, відсутній дидактичний матеріал, розгорнуті форми контролю, які містять самоконтроль. Отже, підручник не сприяє звільненню викладача від рутинної роботи. Із проблемою зняття перевантаження викладача пов'язана і наступна проблема - підручник та освітній процес. У прийнятій традиційній формі підручника цей зв'язок не простежується, оскільки викладач, плануючи заняття, обирає засоби навчання, виходячи з методичної забезпеченості й матеріальної бази кафедри, а не зі специфіки змісту. При виборі методики навчання визначальна роль повинна належати змісту навчання, сконцентрованому в підручнику.

Вивченню змісту параграфрів має передувати активна робота студентів над цим матеріалом. Форми і методи цієї роботи також повинні бути в підручнику. Працюючи над параграфром підручника, студенти одержують інформацію у готовому вигляді. Така методика не стимулює їх розвиток, оскільки розрахована на запам'ятовування. Підручник нового типу спрямовує студентів на пошук необхідних знань, визначає проблеми й дає зразки їх вирішення, пропонує зробити висновки, допомагає виконати самоконтроль засвоєння матеріалу $\mathrm{i} i \mathrm{i}$. Таким чином, підручник повинен містити основну інформацію і способи ії засвоєння. Блоки самопідготовки й самоперевірки, пошук алгоритму допоможуть студентам навчитися застосовувати знання на практиці.

Актуальним є питання про взаємозв'язок підручника й освітнього процесу. Матеріал підручника має бути організований так, щоб давати простір викладачу для творчого застосування пропонованих підручником форм роботи над змістом. Повільне впровадження в практику багатьох досягнень педагогічних наук пояснюється тим, що вони не знаходять реального втілення, насамперед, у підручниках. При такій структурі підручника відобразити новаторський педагогічний досвід неможливо. Ми переконались, що підручник повинен містити зразки проблемного, диференційованого навчання, мати опис нових прийомів i форм навчальної роботи, цікавих методичних знахідок, а завдання викладача полягає в тому, щоб побудувати із цих елементів методичний комплекс, оптимально спрямований на досягнення успіху в навчанні. Розроблений нами підручник багатокомпонентної структури «Медична фізика» складений відповідно до викладених вище принципів.

Поява нового типу навчального інформаційного простору дає можливість зовсім по-новому підійти до організації освітнього процесу з 
використанням підручника, зокрема електронного. Наявні електронні підручники з медичної фрізики мають традиційний інформаційний матеріал, представлений в електронному вигляді. Як показує досвід роботи в університеті, такий підручник не виконує свої функціональні можливості в повній мірі, не викликає цікавість, допитливість, мотивацію студентів до навчання, та й користуватися паперовим підручником більш зручно, ніж його електронною версією. Тому актуальним $\epsilon$ розробка принципово нового електронного підручника, який був би не заміною друкованого.

Під електронним підручником розуміємо комп'ютерну програму, яка містить навчальну інформацію і програмні засоби, що дозволяють студенту отримувати додаткові відомості, проводити тренінг, самоконтроль знань, а викладачеві здійснювати контроль за ходом вивчення дисципліни. Електронний підручник повинен дозволити оптимізувати управління навчанням, значно підвищити ефективність і об'єктивність освітнього процесу i, безумовно, заощадити час і сили викладача. На кафедрі медичної фрізики, біофізики і вищої математики Запорізького державного медичного університету здійснюється розробка електронного підручника з медичної фрізики, зокрема ведеться підготовка навчально-методичних матеріалів, які увійдуть до нього.

Висновки. Завдяки багатокомпонентній структурі підручника можна, крім звичайного заучування, привчати студентів до різних видів навчальної діяльності Скорочення обсягу підручника за рахунок зменшення обсягу математичних викладок та розрахунків не повинно приводити до вилучення 3 освітнього процесу роботи над цим матеріалом. Розрахунки та виведення законів і формул ми вважаємо доцільним перенести в збірник для практичних занять. На наш погляд, об'єднання електронного підручника з програмами, що контролюють знання, доповнене спілкуванням між викладачем і студентом в реальному часі мають великі перспективи для ефективного проведення навчання, в тому числі й дистанційного.

\section{Література}

Атаманчук П. С. Прогнозування фрізичної освіти в умовах особистісно орієнтованого навчання // Методологічні принципи формування фізичних знань учнів і професійних якостей майбутніх учителів фрізики та астрономії : збірник наукових праць. Кам'янець-Подільський державний університет, 2003. С. 11.

Ємчик, Л.Ф., Кміт Я.М. Медична і біологічна фрізика : підручник. Львів : Світ, 2003. 592 с.

Медична та біологічна фрізика / [за ред. В. Г. Кнігавко]. Харків, 2009. 212 с.

Тиманюк, В.А. Биофизика : учеб. для студентов фармац. и мед. вузов / [В.А.Тиманюк, Е.Н.Животова]. Харків : Золотые страницы, 2003. 704 с.

Точиліна Т.М. Теоретичні та методичні основи розробки методичної системи ефективного навчання фрізиці у технічному університеті // Науковий журнал Сумського держ. пед. університету ім. А.С. Макаренка «Педагогічні науки: теорія, історія, інноваційні технології» №5 (23). Суми : Вид-во СумДПУ імені А.С.Макаренка, 2012. С.165-172 
Точиліна Т.М. Основні принципи відбору змісту навчального матеріалу при вивченні фрізики у вищих технічних навчальних закладів // Вісник Черкаського Національного університету імені Б.Хмельницького. №12 (225). Серія: педагогічні науки. Черкаси, 2012. С.132- 137.

Чалий О.В. Медична і біологічна фрізика: підручник. Київ : Нова книга, 2017. 528 c.

Шаповаленко С.Г. Підручник у системі засобів навчання. Москва, 2004. $113 \mathrm{c}$.

\section{References}

Atamanchuk, P.S. (2003). Prohnozuvannia fizychnoi osvity $v$ umovakh osobystisno oriientovanoho navchannia [Forecasting physical education in the context of personality-oriented learning]. Metodolohichni pryntsypy formuvannia fizychnykh znan uchniv i profesiinykh yakostei maibutnikh uchyteliv fizyky ta astronomii : zbirnyk naukovykh prats. Kamianets-Podilskyi derzhavnyi universytet.

Yemchyk, L.F., Kmit, Ya.M. (2003) Medychna i biolohichna fizyka [Medical and biological physics] : pidruchnyk. Lviv : Svit. $592 \mathrm{~s}$.

Knihavko, V. H. (2009) Medychna ta biolohichna fizyka [Medical and biological physics]. Kharkiv. $212 \mathrm{~s}$.

Tymaniuk, V.A., Zhyvotova, E.N. (2003) Byofyzyka [Biophysics] : ucheb. dlia studentov farmats. y med. vuzov. Kharkiv : Zolotye stranytsy. 704 s.

Tochylina, T.M. (2012) Teoretychni ta metodychni osnovy rozrobky metodychnoi systemy efektyvnoho navchannia fizytsi u tekhnichnomu universyteti [Theoretical and methodical bases of development of methodical system of effective teaching of physics in technical university]. Naukovyi zhurnal Sumskoho derzh. ped. universytetu im. A.S. Makarenka "Pedahohichni nauky: teoriia, istoriia, innovatsiini tekhnolohii». №5 (23). Sumy : Vyd-vo SumDPU imeni A.S.Makarenka. S.165-172

Tochylina, T.M. (2012) Osnovni pryntsypy vidboru zmistu navchalnoho materialu pry vyvchenni fizyky u vyshchykh tekhnichnykh navchalnykh zakladiv [Basic principles of selection of the content of educational material in the study of physics in higher technical educational institutions]. Visnyk Cherkaskoho Natsionalnoho universytetu imeni B.Khmelnytskoho. №12 (225). Seriia: pedahohichni nauky. Cherkasy. S. 132-137.

Chalyi, O.V. (2017) Medychna i biolohichna fizyka [Medical and biological physics] : pidruchnyk. Kyiv : Nova knyha. $528 \mathrm{~s}$.

Shapovalenko, S.H. (2004) Pidruchnyk u systemi zasobiv navchannia [Textbook in the system of teaching aids]. Moscow. $113 \mathrm{~s}$.

\section{АНОТАЦІЯ}

У пропонованій статті проаналізовано роль фрізики в розвитку сучасної медицини. Розглянуті принципів ефективного навчання медичній та біологічній фрізиці. Розкриті умови, які забезпечують формування позитивної мотивації навчальної діяльності в процесі навчання медичній фрізиці. Визначенні основні педагогічні функції підручника в освітньому процесі. Зроблено аналіз деяких проблем наявних підручників з медичної фрізики для вищих медичних закладів освіти та запропоновані можливі шляхи їх вирішення. Зроблено структурнологічний аналіз навчального тексту змістового модуля "Біоакустика. Біофрізика чуття. Основи аудіометрії», проаналізовано виклад змісту теорії в підручнику "Медична та біологічна фрізика» Чалого О.В. Дається опис основних структурних елементів розробленого нами підручника з медичної фрізики. Розглянуті сучасні підходи до організації освітнього процесу 3 використанням електронного підручника з медичної фрізики. Обгрунтовано 
актуальність розробки принципово нового електронного підручника, який був би не заміною друкованого.

Надано визначення електронного підручника. Під електронним підручником розуміємо комп'ютерну програму, яка містить навчальну інфоормацію і програмні засоби, що дозволяють студенту отримувати додаткові відомості, проводити треніне, самоконтроль знань, а викладачеві здійснювати контроль за ходом вивчення дисципліни.

Зроблено висновки, що скорочення обсягу підручника за рахунок зменшення обсягів математичних викладок та розрахунків не повинно призводити до вилучення з освітнього процесу роботи над цим матеріалом. Розрахунки та виведення законів та фрормул ми вважаємо доцільним перенести в збірник для практичних занять. На наш погляд, об'єднання електронного підручника з програмами, які контролюють знання, доповнене спілкуванням між викладачем $і$ студентом у реальному часі мають великі перспективи для ефрективного проведення навчання, в тому числі й дистанційного.

Ключові слова: медична фрізика, біомедичні дослідження, медичні технології, ефективність навчання, електронний підручник. 